\title{
PERFORMANCES DE GÊNERO E TEATRO DO OPRIMIDO DESCONSTRUINDO VELHAS NARRATIVAS E PROPONDO NOVAS
}

Wograine Evelyn é aluna de Letras da PUC-Rio

E-mail:wograine@ hotmail.com

\author{
Resumo \\ O artigo objetiva analisar, através da transcrição de \\ vídeos, como a identidade de jovens moradores de \\ uma comunidade foi construída durante uma \\ oficina de Teatro do Oprimido sobre questões de \\ gênero. Acredita-se que o projeto possa \\ instrumentalizar, via exercício teatral, a ação social \\ responsiva às inúmeras práticas de violência física \\ e simbólica ancoradas em concepções \\ essencializantes, opressivas e \\ estigmatizadoras sobre gênero.
}

\begin{abstract}
This article aims to analyze the identity construction of young people in disadvantaged communities during a workshop of Theatre of the Oppressed based on a theoretical review of previous gender and sexuality studies. It is believed that this workshop might promote critical social responses to well-known practices of both physical and symbolic violence, which are based on hegemonic views on gender and sexuality.

O ato de contarmos e ouvirmos histórias tem um papel crucial na construção de nossas vidas e das vidas dos outros. Moita Lopes
\end{abstract}

\section{1) Introdução}

Este artigo é resultado de uma pesquisa iniciada em 2014 e motivada por três pressupostos: (1) a escassa quantidade de estudos que se voltam para questões de gênero fora do âmbito acadêmico exclusivo; (2) a importância de se estabelecer, em espaços pedagógicos, discussões que desnaturalizem paradigmas opressores; e (3) a experimentação do teatro como espaço lúdico-pedagógico e de intervenção política.

$\mathrm{Na}$ fase inicial do projeto, foi formulada uma sequência de jogos teatrais oriundos do Teatro do Oprimido com o intuito de fazer emergir questões de gênero e de promover performances orientadas para a desconstrução de sentidos solidificados no que concerne a masculinidades e feminilidades hegemônicas. A sequência de jogos, que aqui chamaremos de oficina, foi aplicada no primeiro semestre de 2015, em uma comunidade, para jovens e adolescentes de 13 a 19 anos. Por questões de tempo, a noção de Teatro do Oprimido não será abordada com profundidade no artigo, mas trata-se de uma metodologia de teatro criada por Augusto Boal (1991) para atores e não atores ${ }^{1}$. A metodologia objetiva, através da construção de uma cena ou de um jogo teatral, a criação de possibilidades de saída de situações opressoras.

$\mathrm{O}$ artigo, como atividade final do projeto, se propõe a apresentar e discutir algumas performances discursivas que ocorreram no decorrer dos jogos e cenas propostos, mas, antes de darmos início a apresentação dos dados, é imprescindível indicar as bases teóricas que orientam a análise dessas performances. Sendo assim, a primeira parte do artigo é

${ }^{1}$ No artigo de Evelyn e Biar (2015) Teatro do Oprimido e performances de gênero: uma proposta de intervenção, que também é referente a essa pesquisa - ao processo embrionário dela -, é possível encontrar uma revisão bibliográfica maior sobre o Teatro do Oprimido, caso venha interessar ao leitor. 
dedicada às teorias sobre identidade no mundo pós-moderno, isto é, seus atributos. Em seguida, abordamos importantes conceitos e teorias acerca de questões gênero. Na terceira parte, analisamos a oficina, ou seja, as atividades realizadas, e, por fim, trazemos algumas considerações sobre o presente estudo.

\section{2) QUESTÕES DE IDENTIDADE}

O recorte que interessa neste artigo acerca do conceito de identidade é o entendimento que se tem de sujeito na chamada pós-modernidade. Isso significa que partimos de uma visão construcionista e não essencialista do sujeito. Para entendermos melhor esses atributos, primeiramente, mencionaremos Stuart Hall (2006), que distinguiu três tipos diferentes de identidade ao longo da história: o Sujeito Iluminista, o Sujeito Sociológico e o Sujeito Pós-Moderno. O primeiro deles também pode ser entendido como cartesiano, isto é, um sujeito consciente e pensante, o indivíduo indivisível, situado no centro do conhecimento. O Sujeito Iluminista deve ser compreendido como um ser dotado de uma essência, que é o atributo que o singulariza. Como explica Hall:

O sujeito do Iluminismo estava baseado numa concepção da pessoa humana como um indivíduo totalmente centrado, unificado, dotado das capacidades de razão, de consciência e de ação, cujo "centro" consistia num núcleo interior, que pela primeira vez quando o sujeito nascia e com ele se desenvolvia, ainda que permanecendo essencialmente o mesmo — continuo ou "idêntico" a ele — ao longo da existência do indivíduo. O centro essencial do eu era a identidade de uma pessoa. (HALL, 2006, p. 10, ênfases no original)

A noção de Sujeito Sociológico difere da noção de Sujeito Iluminista porque com ela se reconhece que aspectos sociais também são relevantes para a formação de uma identidade. Nesse caso, a identidade seria formada a partir da interação entre o "eu" essência - e a sociedade. Desse modo:

A noção de sujeito sociológico refletia a crescente complexidade do mundo moderno e a consciência de que este núcleo interior do sujeito não era autônomo e auto-suficiente, mas era formado na relação com "outras pessoas importantes para ele", que mediavam para o sujeito os valores, sentidos e símbolos - a cultura - dos mundos que ele/ela habitava. (...) O sujeito ainda tem um núcleo ou essência interior que é o "eu real", mas este é formado e modificado num diálogo contínuo com os mundos culturais "exteriores" e as identidades que esses mundos oferecem. (HALL, 2006, p. 11, ênfases no original)

Com a noção de Sujeito Pós-Moderno, desponta o sujeito fragmentado e multifacetado. O sujeito na pós-modernidade já não possui uma essência, e a identidade, nesse caso, não pode mais ser vista como unificada e estável, uma vez que o sujeito é composto de inúmeras identidades - e não de uma só. Então, ao contrário, a identidade é múltipla, variável, provisória e, muitas vezes, contraditória. Informações como classe, sexo, sexualidade, etnia e nacionalidade, que antes forneciam sólidas localizações dos indivíduos sociais, agora só exprimem possibilidades de representatividade que por vezes 
podem se cruzar ou até mesmo entrar em confronto. O que difere o Sujeito Pós-Moderno dos Sujeitos Iluminista e Sociológico é que, enquanto que nesses últimos a questão da essência prevalece, no Sujeito Pós-Moderno há o apagamento da existência de uma essência universal do homem. De acordo com Hall:

Ao invés disso, à medida em que os sistemas de significação e representação cultural se multiplicam, somos confrontados por uma multiplicidade desconcertante e cambiante de identidades possíveis, com cada unia das quais poderíamos nos identificar - ao menos temporariamente. (HALL, 2006, p. 12 - 13)

Sobre a ocorrência desse sujeito sem uma identidade fixa, essencial ou permanente, também nos fala o sociólogo Bauman (2001), que aponta para o atributo marcador e definidor dos tempos pós-modernos: a liquidez. Seja na área econômica, seja na política, na pessoal ou na social, o que se presume é que a solidez da identidade e das relações de outrora abriu espaço para um mundo inconstante que parece exigir que as pessoas tenham grande capacidade de adaptação e desapego. Segundo Bauman:

\begin{abstract}
Enquanto os sólidos têm dimensões espaciais claras, mas neutralizam o impacto e, portanto, diminuem a significação do tempo (resistem efetivamente a seu fluxo ou o tornam irrelevante), os fluidos não se atêm muito a qualquer forma e estão constantemente prontos (e propensos) a mudá-la (...) Essas são razões para considerar "fluidez" ou "liquidez" como metáforas adequadas quando queremos captar a natureza da presente fase, nova de muitas maneiras, na história da modernidade (BAUMAN, 2001, p. 8-9, ênfases no original)
\end{abstract}

Como suplemento às teorias apresentadas, temos também o professor Tomaz Tadeu da Silva (2000), que levanta pontos pertinentes para a discussão do artigo, como, por exemplo, a questão da interdependência entre identidade e diferença, por exemplo. Silva (2000) defende que a identidade é produzida sempre através de uma negação e por causa de uma negação, e não, como poderíamos imaginar, por afirmações. Por exemplo, quando alguém afirma: sou brasileira, sou branca ou sou casada, na verdade, nega uma cadeia de possibilidades, e, então, afirma também: não sou francesa, não sou negra, não sou parda, não sou solteira, não sou viúva, não sou japonesa. Afirmações servem e funcionam como simplificações, cadeias de negações implícitas e inevitáveis no interior semântico das proposições que produzem a identidade. Sobre identidade e diferença, Silva nos fala:

Além de serem interdependentes, identidade e diferença partilham uma importante característica: elas são o resultado de atos de criação linguística. Dizer que são o resultado de atos de criação significa dizer que não são "elementos" da natureza, que não são essências, que não são coisas que estejam simplesmente aí, à espera de serem reveladas ou descobertas, respeitadas ou toleradas. A identidade e a diferença tem que ser ativamente produzidas (...). Somos nós que as fabricamos, no contexto de relações culturais e sociais. (SILVA, 2000, p. 76, ênfases no original) 
Neste fragmento, além de o autor se alinhar às teorias de Hall e Bauman no que tange o caráter não essencial da identidade, ele também retoma o caráter construcionista dela, declarado no início da sessão. Se a identidade é fragmentada, logo, não é unificada. Se é mutável, $\log o$, não é fixa. Se é líquida, logo, não é sólida. Se é provisória, logo, não é permanente. Se a identidade é uma construção, ela não pode ser uma essência. No fragmento acima, Silva também pontua um dado significativo: identidade, assim como a diferença, é um produto da linguagem. É através do nosso discurso que construímos o que somos.

Silva (2000) menciona Judith Butler (2003) como uma autora que teoriza para complicar e subverter as identidades que se naturalizaram. Buscando organizar o raciocínio de Butler (2003), Silva (2000) afirma: 1) a identidade depende da linguagem, 2) a linguagem se sujeita a uma ordem de poder, 3) uma ordem de poder estabelece normas valorativas, 4) e essas normas, com o passar do tempo, por serem constantemente reproduzidas, se naturalizam.

Para entender em que sentido a linguagem se submete a vetores de força, basta pensarmos que aqueles que estão no topo das relações de poder é que irão impor as nomenclaturas, os atos de criação linguística, assim como seus valores. Quem tem o poder de definir, também tem poder de criar binarismos, valorar as produções de identidade criando identidades "melhores" e, consequentemente, outras "piores", na medida em que podem incluir, excluir, classificar e normalizar através da linguagem. Como afirma Silva:

\begin{abstract}
Normalizar significa eleger arbitrariamente - uma identidade específica como parâmetro em relação ao qual as outras identidades são avaliadas e hierarquizadas. Normalizar significa atribuir a essa identidade todas as características positivas possíveis, em relação as quais as outras identidades só podem ser avaliadas de forma negativa. A identidade normal é "natural", desejável, única. (...) Assim como a definição da identidade depende da diferença, a definição do normal depende da definição do anormal. (...) A definição daquilo que é considerado aceitável, desejável, natural, é inteiramente dependente da definição daquilo que é considerado abjeto, rejeitável, antinatural. (SILVA, 2000, p. 83, ênfases no original)
\end{abstract}

Ainda reportando-se à Butler (2003), Silva (2000) demonstra como a autora, que desenvolveu o conceito de performatividade, foi inspirada pelo linguista J.A. Austin. Silva (2000) explica que, de acordo com a teoria de Austin, haveria dois tipos de proposições/sentenças: as descritivas e as performativas. As proposições descritivas seriam aquelas que somente descrevem ou constatam algo, por exemplo, "o suco está na geladeira". Já as proposições performativas seriam aquelas que não apenas descrevem, mas que fazem com que algo aconteça, se efetue ou se realize de forma concreta. Dessa forma, "em seu sentido estrito, só podem ser consideradas performativas aquelas proposições cuja enunciação é absolutamente necessária para a consecução do resultado que anunciam" (SILVA, 2000, p. 93). Seria um exemplo clássico de proposição performativa a sentença “eu vos declaro marido e mulher", pois a pessoa que a pronuncia, dotada de poder para isso, concretiza o matrimônio. 
Para Butler (2003), identidade seria, nessa lógica, uma questão de performatividade, ou seja, ela seria construída pela linguagem, concretizada através do discurso. Performatividade, para a autora, "deve ser compreendida não como um 'ato' singular ou deliberado, mas, ao invés disso, como a prática reiterativa e citacional pela qual o discurso produz os efeitos que ele nomeia" (BUTLER, 2000, p. 111). Butler (2000) parece querer nos lembrar que, como também vemos em Silva (2000), a linguagem tem estrita relação com vetores de poder. A autora continua: performatividade "não é, assim, um "ato" singular, pois ela é sempre uma reiteração de uma norma ou conjunto de normas" (BUTLER, 2000, p. 121). Em Silva (2000), encontramos:

Em geral, ao dizer algo sobre certas características identitárias de algum grupo cultural, achamos que estamos simplesmente descrevendo uma situação existente, um "fato" do mundo social. O que esquecemos é que aquilo que dizemos faz parte de uma rede mais ampla de atos linguísticos que, em seu conjunto, contribui para definir ou reforçar a identidade que supostamente só estamos descrevendo. Assim, por exemplo, quando utilizamos uma palavra racista como "negrão" para nos referir a uma pessoa negra do sexo masculino, não estamos simplesmente fazendo uma descrição sobre a cor da pessoa. Estamos, na verdade, inserindo-nos em um sistema linguístico mais amplo que contribui para reforçar a negatividade atribuída à identidade negra. (SILVA, 2000, p. 93, ênfases no original)

Para Butler (2003), o modo de se desestabilizar a eficácia de atos performativos que reforçam identidades normalizadas, opressoras e hegemônicas é interrompendo a repetibilidade delas, uma vez que é através da repetição contínua que elas se perpetuam tornando-se naturais. Por esta razão, é importante mencionarmos o trabalho de Moita Lopes (2006), um especialista em linguística aplicada. O autor, assim como os teóricos acima já citados, também afirma que as identidades sociais são construídas em práticas discursivas. Moita Lopes (2006) evidencia em sua obra a participação e interferência do outro na produção discursiva da identidade: "ao considerarmos as identidades sociais de nossos interlocutores ao nos engajarmos no discurso, estamos simultaneamente (re-) construindo nossas identidades sociais ao passo que eles estão também (re-) construindo as nossas" (MOITA LOPES, 2006, p. 62).

Além disso, a maior contribuição de Moita Lopes (2006) para a presente pesquisa é sua investigação no que tange a construção de identidade de alunos em sala de aula - o espaço pedagógico tradicional por excelência. Ele investiga como a identidade é construída por estudantes e, especialmente, como os professores problematizam e lidam com as questões voltadas para esse tema. Em seu livro Identidades Fragmentadas, ele investiga uma sala de aula de uma turma de $5^{\text {a }}$ série de uma escola pública e percebe que diversas vezes a identidade é tratada de forma essencialista, isto é, as características físicas, sociais ou psicológicas dos alunos são reafirmadas pelos professores como naturais, não há problematizações acerca das razões que levam certas identidades a serem compreendidas como melhores ou piores, normais ou anormais. Moita Lopes afirma:

Como diz Brunner (1996), a educação é crucial na construção de quem somos. Isso quer dizer que os significados construídos na escola sobre a vida social, paralelamente a outros 
significados a que somos expostos em outras práticas discursivas das quais participamos, desempenham papel central na legitimação das identidades sociais. É na escola, porém, que as crianças, em geral, se expõem, pela primeira vez, a significados que podem contestar ou confirmar quem elas são com base em como suas identidades foram construídas na família. (MOITA LOPES, 2006, p.59)

Para Moita Lopes (2006), a escola tem sua cota de responsabilidade pela reprodução de discursos opressores e o currículo escolar deveria se dispor a discutir questões em sala de aula que visem uma mudança social, pois o discurso produzido pelo professor tem grandes chances de ser reproduzido pelos alunos, já que, socialmente, o professor ocupa um lugar de respeito. Moita Lopes (2006) propõe que se criem novas narrativas em sala de aula capazes de quebrar cânones culturais - que, para o autor, são as expectativas culturais de um grupo -, narrativas metalinguísticas que examinem quem conta e por que se contam repetidamente certas narrativas. Fazer estudantes perceberem como a sociedade é permeada de construções sociais, de algum modo, possibilitaria, para Moita Lopes, construir uma nova história. Segundo o autor:

A percepção do discurso como construção social coloca as pessoas como participantes nos processos de construção de significado na sociedade e, portanto, inclui a possibilidade de permitir posições de resistência em relação a discursos hegemônicos, isto é, o poder não é tomado como monolítico a as identidades sociais não são fixas. (MOITA LOPES, 2006, p. 55)

Sendo assim, a proposta de criação de novas narrativas de Moita Lopes (2006), de algum modo, ajuda a interromper as reiterações de um discurso hegemônico opressor, além disso, a proposta abre espaço para a resistência. A sequência de jogos teatrais criada especificamente para esta pesquisa possui o mesmo fim: desestabilizar a repetição de paradigmas opressores sobre gênero e propor novas narrativas dentro de um espaço lúdico-pedagógico.

\section{3) QUESTÕES DE GÊNERO E SEXUALIDADE}

Antes de apresentarmos alguns teóricos importantes no que tange questões de gênero, primeiro, precisamos estabelecer uma divisão clara a respeito das concepções de sexo, gênero e sexualidade, três conceitos-chave para a discussão, que, antigamente, não significavam coisas diferentes, dissociáveis e socioconstruídas. O primeiro deles, sexo, tem a ver com o dado físico e biológico que determina a qual categoria um indivíduo vai pertencer: homem ou mulher. $\mathrm{O}$ segundo, gênero, concerne à apresentação social do indivíduo, como ele se apresenta de acordo com padrões e normas que estabelecem uma identidade feminina ou masculina. E o terceiro, sexualidade, diz respeito ao desejo, a que tipos de práticas interacionais, afetivas ou sexuais o indivíduo possui.

Simone de Beauvoir (1967) foi uma das primeiras a questionar a naturalidade do gênero. Com a publicação do polêmico livro $O$ segundo sexo, ela nos deixa o célebre sintagma "a gente não nasce mulher, torna-se mulher". Mas o que isto poderia significar, se não que 
toda pessoa, dotada do órgão genital feminino, aprende tacitamente a reproduzir as normas e padrões que definem a identidade feminina? Seguindo essa lógica, percebemos que noções como feminilidade, fragilidade ou delicadeza perdem seu sentido, se entendidas como naturais da mulher. Nesse caso, a identidade "mulher", ou mesmo a identidade "homem", não seria dotada de uma essência, ao contrário, seriam construções arbitrárias que se perpetuam através da reiteração de um discurso (Butler).

Foucault (1988), seguindo Beauvoir (1967), desestabiliza nossas seguranças sobre o que tange o tema da sexualidade. O autor cria o conceito de "dispositivo histórico" para explicar que - como o próprio título de seu livro sugere: História da sexualidade - a noção de sexualidade foi inventada dentro de um período específico e localizável a partir de discursos reguladores que produzem regimes de verdade. Assim, "os atributos de gênero e sexualidade não preexistem ao discurso que os fundou sob condições históricas e demandas institucionais bem definidas”. (EVELYN e BIAR, 2015, p. 2)

Se, através dos trabalhos de Beauvoir (1967) e Foucault (1988), gênero e sexualidade puderam ser entendidos como construções simbólicas não naturais, no trabalho de Butler, também a noção de sexo foi desnaturalizada. Apoiando-se no conceito de "dispositivo histórico" de Foucault (1988), Judith Butler (2003) demonstra que o sexo - definição biológica que institui binariamente as categorias macho/fêmea, homem/mulher - é também um constructo cultural arbitrário localizável no tempo que foi naturalizado em processos discursivos. Butler explica:

a linguagem é um conjunto de atos, repetidos ao longo do tempo, que produzem efeitos de realidade que acabam sendo percebidos como "fatos". Considerada coletivamente, a prática repetida de nomear a diferença sexual criou essa aparência de divisão natural. A "nomeação" do sexo é um ato de dominação e coerção, um ato performativo institucionalizado que cria e legisla a realidade social pela exigência de uma construção discursiva/perceptiva dos corpos, segundo os princípios da diferença sexual. (BUTLER, 2003, p. 169, ênfases no original)

Parece que Butler culpa as instituições detentoras do poder pelo efeito de naturalidade que as categorias de sexo alcançaram. Foi instituindo o binarismo macho/fêmea e reiterando-o historicamente que a divisão sexual "homem e mulher" ganhou a aparência falaciosa de fato natural. Para a autora, "a performatividade de gênero não pode ser teorizada separadamente da prática forçosa e reiterativa dos regimes sexuais regulatórios" (BUTLER, 2000, p. 123).

$\mathrm{Na}$ medida em que as teorias sobre identidade pós-moderna passaram a entender a identidade do sujeito como socioconstruída, outras áreas de estudo foram assumindo esse caráter construcionista também. É o que acontece com as questões de gênero, que já não assume nenhuma categoria como natural em seu território, mas produzidas através de práticas discursivas e atos linguísticos. Se a identidade de gênero é também uma das múltiplas possibilidades da construção de identidade de um sujeito, nada seria mais lógico do que também considerá-la como não fixa, não essencial, não permanente e não sólida. Nessa perspectiva, não só analisaremos em que extremos foram construídas 
discursivamente as identidades durante a oficina de teatro - extremos essencialista ou construcionista -, como também investigaremos se as teorias referidas foram, de maneira implícita, apresentadas aos participantes de modo que pudesse interromper a repetibilidade de certas narrativas e fazê-los confrontarem novas.

\section{4) A APLICAÇÃO DOS JOGOS E AS CENAS}

A oficina de Teatro do Oprimido constitui-se 13 aulas com duração de uma hora e meia cada, acumulando um total de quase vinte horas de gravação, ela foi aplicada dentro de uma ONG situada em uma comunidade do Rio de Janeiro. Desse modo, foi parte do currículo de atividades que os participantes do projeto da ONG tinham que cumprir. Entre as outras atividades, das quais os jovens, todos de idade entre 13 e 19 anos, participavam, havia, por exemplo, aulas de inglês e informática. Neste artigo, serão analisadas seis das atividades propostas, cada uma delas contribuindo de algum modo com nosso objetivo.

A primeira atividade para a qual chamaremos atenção chama-se Jogo dos brinquedos. Neste exercício, os participantes foram estimulados a responder certas perguntas sobre dois grupos de brinquedos espalhados pela sala. Em um grupo, havia brinquedos associados tipicamente à identidade feminina, como bonecas e bichos de pelúcia, e, no outro, havia brinquedos associados tipicamente à identidade masculina, como bola de futebol, uma luva de baseball e um videogame. Alguns objetos que não são, ou são de forma controvérsia, tipicamente mais associados nem com a identidade masculina nem com a feminina também foram postos em jogo: no grupo das bonecas, havia uma caixa de lápis de cores, e, no grupo da bola, um globo do mundo, um CD de funk e uma bicicleta.

Após dividir os brinquedos, o professor fez uma primeira indagação aos alunos, ele perguntou qual dos dois grupos de objetos possuía os brinquedos mais utilizados por eles na infância. Das cinco meninas que estavam presentes, quatro apontaram rapidamente para o grupo das bonecas, exceto Julia. Já dos dois meninos presentes, um afirmou que não brincava com os brinquedos de nenhum dos grupos, enquanto o outro afirmou brincar com a bola. De alguma maneira, a resposta dos meninos faz todo o sentido, já que baseball não é um esporte muito praticado no Brasil, o globo pode ser utilizado mais em contextos de estudo do que para brincar, o CD de funk seria relativo ao gosto musical e o videogame e a bicicleta não são brinquedos acessíveis a todos.

A segunda pergunta foi sobre com qual grupo de brinquedos eles gostariam de brincar com a idade que estão agora. Das cinco meninas, quatro apontaram para as bonecas, e apenas Thaís apontou para o grupo da bola, junto com os dois meninos. $\mathrm{Na}$ terceira parte do exercício, iniciamos uma discussão sobre o assunto.

Microcena 1

\begin{tabular}{|c|c|c|}
\hline $\begin{array}{l}1 \\
2\end{array}$ & $\mathrm{P} 1$ & $\begin{array}{l}\text { A divisão que eu fiz foi homens e mulheres, mas eu acho eu posso desconstruir toda essa } \\
\text { essa construção que eu fiz e }\end{array}$ \\
\hline 3 & Julia & [Eu acho que boneca é pra menina] \\
\hline 4 & $\mathrm{P} 1$ & É pra menina? \\
\hline
\end{tabular}




\begin{tabular}{|c|c|c|}
\hline 5 & Julia & Eu acho que é. \\
\hline 6 & P1 & Se acha que um menino não poderia ter uma \\
\hline 7 & Ana & {$\left[{ }^{\circ}\right.$ Seria estranho $\left.{ }^{\circ}.\right]$} \\
\hline 8 & Julia & [Eu acho que não.] \\
\hline 9 & & $(($ Burburinho $))$ \\
\hline 10 & Thais & Eu acho que ele poderia se ele quisesse, se ele tivesse vontade de comprar uma. \\
\hline $\begin{array}{l}11 \\
12\end{array}$ & P1 & $\begin{array}{l}\text { Todo mundo acha que:: é ela já não (.) quem aqui acha que um menino poderia sim } \\
\text { brincar com um bichinho de pelúcia? }\end{array}$ \\
\hline 13 & Thais & Porque pra mim brinquedo não tem gênero. \\
\hline $\begin{array}{l}14 \\
15\end{array}$ & P1 & Não tem gênero. Por exemplo, um menino não poderia entrar na brincadeira de ser o pai? \\
\hline 16 & Henrique & ${ }^{\circ} \mathrm{E}^{\circ}$ \\
\hline 17 & P1 & Não poderia? \\
\hline 18 & Henrique & ${ }^{\circ}$ Pode. ${ }^{\circ}$ \\
\hline 19 & Julia & Poderia mas eu acho que é \\
\hline 20 & Henrique & {$\left[{ }^{\circ}\right.$ Poderia $\left.\operatorname{sim}^{\circ}\right]$} \\
\hline 21 & P1 & [E ser a mãe?] ((risos)) Quem sabe? \\
\hline 22 & Julia & É ai eu não sei, no geral seria muito estranho ((risos)) \\
\hline 23 & P1 & Mas será que ele entra nessa brincadeira ... ou não? \\
\hline 24 & Thais & É raro encontrar uma criança que queira né, tem menino que \\
\hline 25 & $\mathrm{P} 2$ & [Mas por que que você acha que é raro?] \\
\hline $\begin{array}{l}26 \\
27\end{array}$ & Thais & $\begin{array}{l}\text { Por que? ... Ah::, por causa dos padrões de hoje em dia, a mãe já bota na cabeça do filho } \\
\text { desde pequeno que brinquedo ((inaudível)) }\end{array}$ \\
\hline 28 & P1 & A mãe já compra, né? Os brinquedos que ele vai brincar, né. \\
\hline 29 & Thais & É. \\
\hline $\begin{array}{l}30 \\
31\end{array}$ & P1 & $\begin{array}{l}\text { A gente não brinca com certos tipos de coisa porque compraram pra gente certos tipos } \\
\text { de coisa? E não porque a gente escolheu ter certos tipos de coisa? }\end{array}$ \\
\hline 32 & Thais & E se um menino quiser brincar com uma boneca \\
\hline 33 & Julia & [não falam nem da criança que escolhe comprar] \\
\hline $\begin{array}{l}34 \\
35\end{array}$ & P1 & $\begin{array}{l}\text { É, que escolhe comprar. Mas, assim, geralmente, quando quando uma menina nasce, e } \\
\text { os pais podem pintar e decorar o quarto o dela, geralmente ele vai pintar de que cor? }\end{array}$ \\
\hline 36 & & (( o grupo responde em coro: "rosa")) \\
\hline 37 & P1 & E vão colocar o quê no quarto dela? \\
\hline 38 & Julia & Bonecas. \\
\hline $\begin{array}{l}39 \\
40 \\
41 \\
42\end{array}$ & P1 & $\begin{array}{l}\text { Então, de certo modo, pode ser que claro que depois ela escolhe: tanto é que a menina } \\
\text { vai lá e escolhe pai quero uma bicicleta. Eu quero essa boneca x, mas existe também } \\
\text { essa coisa de você tá o tempo todo aprendendo é a definir quais brinquedos que você } \\
\text { brinca e quais você não brinca, certo? }\end{array}$ \\
\hline
\end{tabular}

${ }^{2} \mathrm{~A}$ forma como foram divididos os brinquedos no início do jogo reitera propositalmente os significados já solidificados e naturalizados sobre gênero masculino e feminino, uma vez que a divisão está embasada no senso comum sobre o binário brinquedos de garota e brinquedos de garoto. Notamos que a professora (P1), na linha 1, ao tentar desconstruir o binarismo homem/mulher presente na divisão dos grupos de brinquedos, é interrompida pelo estranhamento de uma participante que provavelmente

Sobre as convenções de transcrição: $(\mathrm{P} 1, \mathrm{P} 2$ ou P3 $)=$ Professor 1,2 ou 3 , respectivamente, $(\ldots)=$ pausa não medida, $($.$) = pausa de menos de 2$ décimos de segundos, $(-)=$ parada súbita, (sublinhado) $=$ ênfase em 
som, $($ maiúscula $)=$ voz alta, $\left({ }^{\circ}\right.$ palavra $\left.{ }^{\circ}\right)=$ voz baixa, $(>$ palavra $<)=$ fala rápida, $(::)=$ alongamento, $([])=$ fala sobreposta e $(())=$ comentário do analista ou descrição de atividade não vocal.

não está acostumada a ouvir narrativas que estimulem a desconstrução de um cânone cultural. Julia interrompe a professora e reproduz um estereótipo de gênero "eu acho que boneca é para menina" (linha 3). A narrativa se desenrola e Thais, surpreendentemente, constrói um discurso que desnaturaliza os significados solidificados, atendendo, desse modo, a expectativa da professora: "porque pra mim brinquedo não tem gênero" (linha $13)$.

Percebemos também que Henrique reitera o fato de homens poderem brincar de

\begin{tabular}{|c|c|c|}
\hline 1 & P1 & Agora eu vou mudar um pouquinho (.) é:: eu quero que vocês se abracem \\
\hline 2 & & $(($ risos $))$ \\
\hline $\begin{array}{l}3 \\
4\end{array}$ & $\mathrm{P} 1$ & $\begin{array}{l}>\text { Um abraço< me abraça me abraça pode ser assim só um abraço, um abraço. Galera, } \\
\text { esse abraço, que que passa pra vocês esse abraço? }\end{array}$ \\
\hline 5 & Cesar & Amizade. \\
\hline 6 & Joice & Amigos dos Anos 70 que não irmãos. \\
\hline 7 & & $(($ risos $))$ \\
\hline 8 & $\mathrm{P} 1$ & ${ }^{\circ}$ dos $\operatorname{anos} 70^{\circ}$ \\
\hline 9 & $\mathrm{P} 2$ & Por que dos anos 70? Queria entender. \\
\hline 10 & P3 & Pode ser irmão. \\
\hline 11 & $\mathrm{P} 1$ & Pode ser dois irmãos pra tirar uma foto? \\
\hline 12 & Rafaela & ${ }^{\circ}$ Dois irmãos. ${ }^{\circ}$ \\
\hline 13 & Joao & [Eu tinha falado isso ai] \\
\hline 14 & & ((Inaudível)) \\
\hline 15 & P3 & Pode ser pai e filho \\
\hline 16 & P1 & Pode ser pai e filho, quem é pai? \\
\hline 17 & Cesar & O baixinho. \\
\hline 18 & Maria & É, é o Joao ((risos)) \\
\hline 19 & Cesar & Joaozinho, né. \\
\hline 20 & P1 & E aí meninos o que vocês acham? ((Inaudível)) Sei lá não pode \\
\hline $\begin{array}{l}21 \\
22\end{array}$ & P3 & $\begin{array}{l}\text { [Pra mim é um pai e um filho olhando } \\
\text { uma vista conversando sobre a vida o pai tá falando as coisas da vida pra ele.] }\end{array}$ \\
\hline
\end{tabular}

boneca (linhas 18 e 20). Essa reiteração parece significar que em nenhum momento ele sente que sua masculinidade pode ser posta em cheque por ele afirmar também poder brincar com os brinquedos tipicamente entendidos como femininos. Além disso, seu posicionamento parece ser entendido por ele como importante, como se ele representasse, perante a uma turma composta majoritariamente por garotas, a opinião do público masculino sobre a questão. Thais (linha 26) parece entender que a divisão de gênero dos brinquedos é construída na infância, pelos pais, e, assim, o binarismo com sentido solidificado parece ser (re)entendido como socioconstruído até o fim do diálogo.

A segunda atividade a ser mencionada chama-se Jogo das Imagens Congeladas e foi aplicada na quarta aula da oficina. Neste exercício, os participantes foram convidados a explorarem os múltiplos significados que certas imagens podem ter. A apresentação de uma das imagens, que era de duas pessoas se abraçando, resultou em algo curioso. Pedimos que as duplas se alternassem de modo que tivemos a imagem do abraço nos casos: homem/homem, homem/mulher, mulher/mulher, respectivamente. 
No primeiro caso, assim que a professora orientou os dois meninos a se abraçarem, toda a turma caiu em um riso inexplicável, deixando a dupla desconfortável para atender a orientação (linha 2). De algum modo, isso nos induz a acreditar que, naquele contexto, os jovens se apropriam da ideia de que "homens heterossexuais não se abraçam/se tocam", uma ideia que traz à tona o estereótipo recorrentemente carimbado à identidade masculina do "machão insensível". A proposta do abraço foi uma forma de confrontar o paradigma, e o riso, foi a comprovação de que aqueles jovens têm noções fixas quanto à identidade masculina. Em seguida, pedimos um abraço entre homem e mulher:

Microcena 3

\begin{tabular}{|c|c|c|}
\hline $\begin{array}{l}1 \\
2\end{array}$ & $\mathrm{P} 1$ & $\begin{array}{l}\text { Tem que ficar parado, vocês vocês podem encontrar um abraço, vocês querem mudar o } \\
\text { abraço, pode. }\end{array}$ \\
\hline 3 & Pedro & Não, assim tá bom, valeu. \\
\hline 4 & P1 & Assim tá bom? \\
\hline 5 & Grupo & [Ihhhhh namoraaado] \\
\hline 6 & P1 & Galera, o que que quer dizer esse abraço pra vocês? \\
\hline 7 & Ana & Que eles tão namorando. \\
\hline 8 & & ((Burburinho)) \\
\hline 9 & Thais & A mão dele ali tá. \\
\hline 10 & P1 & Mas olha. ((Inaudível)) \\
\hline 11 & $\mathrm{P} 2$ & GENTE. \\
\hline 12 & & ((Inaudível)) \\
\hline 13 & Ana & Que ela deu um pé na bunda dele e não quer mais. ((Inaudível)) \\
\hline 14 & Thais & Não, pra mim ele tá de saco cheio. Essa cara dele assim pro lado. \\
\hline 15 & & ((Inaudível)) \\
\hline 16 & Ana & [Ela é muito chata, sabe] ((Inaudível)) \\
\hline 17 & Thais & [Que ela é chata] \\
\hline \begin{tabular}{l|l}
18 \\
19
\end{tabular} & P3 & $\begin{array}{l}\text { Ué, pode tá passando uma mulher muito bonita e ele tá olhando pra baixo pra não dar } \\
\text { problema. }\end{array}$ \\
\hline 20 & P1 & É ó tá olhando pra outro lado e aí o que que vocês acham? \\
\hline 21 & Ana & Ou ele pode tá tipo achando que ela traiu ele, ${ }^{\circ}$ nossa $^{\circ}$. \\
\hline $\begin{array}{l}22 \\
23\end{array}$ & $\mathrm{P} 1$ & $\begin{array}{l}\text { Mas olha só, vocês acham - vocês só tão propondo assim que a intenção deles só tá } \\
\text { passando por namorado mas eles podem ser amigos? }\end{array}$ \\
\hline 24 & Grupo & Pode. \\
\hline 25 & P1 & Se eles são amigos o que que pode estar rolando ali? \\
\hline 26 & Ana & ${ }^{\circ} \mathrm{Um}_{\mathrm{clima}}{ }^{\circ}$. \\
\hline 27 & & $((\mathrm{RISOS}))$ \\
\hline
\end{tabular}

O desconforto do menino e da menina em ter que se abraçarem continuou (linha1), mas, dessa vez, a reação dos outros participantes foi bem diferente. A primeira resposta deles ao abraço foi associar imediatamente a imagem da dupla a uma relação amorosa (linha 5). Desta vez, os professores sugeriram menos significados, visto que o tema do amor pareceu interessar os alunos e eles mesmos, desse modo, sugeriram possibilidades dentro do tema (linhas 9, 13, 14 e 18). Interessante notar que mesmo quando a professora 
sugeriu o tema da amizade (linha 22), tentando diversificar a leitura da imagem, os alunos retomam a questão do romance, insistindo na relação amorosa (linha 26).

\begin{tabular}{|c|c|c|}
\hline & & Micr \\
\hline 1 & P1 & Tá bom, elas podem ser amigas ou irmãs e tá uma feliz e outra triste. \\
\hline 2 & Joao & A Luíza não quer tirar foto com a irmã. \\
\hline 3 & P1 & A Luíza não quer tirar foto com a irmã e tá triste? \\
\hline 4 & & ((Inaudível)) \\
\hline 5 & $\mathrm{P} 2$ & A Albertina falou que pode ser uma mãe e a filha. \\
\hline 6 & Rafaela & $>$ A filha tá triste a filha tá triste $<$ e a mãe tá consolando. \\
\hline 7 & P1 & Pode ser uma mãe que brigou com a filha. \\
\hline 8 & Sara & ${ }^{\circ}$ Também $^{\circ}$ \\
\hline $\begin{array}{c}9 \\
10\end{array}$ & $\mathrm{P} 1$ & $\begin{array}{l}\text { Também? Mais o que gente? Quero que vocês falem o que está vindo na cabeça de } \\
\text { vocês. }\end{array}$ \\
\hline 11 & P2 & Elas podem ser namoradas. \\
\hline 12 & & $(($ RISOS $))$ \\
\hline 13 & $\mathrm{P} 1$ & [Boa, P2.] E aí? E se fosse? \\
\hline 14 & P2 & [Ué? Só uma imagem.] Não são vocês. \\
\hline 15 & P1 & Não são vocês, é só uma imagem. \\
\hline 16 & & $(($ RISOS $))$ \\
\hline 17 & $\mathrm{P} 1$ & [Galera], com essa proposta do P2? O que que está acontecendo? \\
\hline 18 & Ana & Elas brigaram? ((Inaudível)) Uma tá feliz e outra tá triste. \\
\hline
\end{tabular}

Quando é a vez de duas meninas se abraçarem, não há burburinho e o exercício segue sem risos ou brincadeiras. Isso significa que, dentro do contexto estudado, o abraço está "permitido" entre duas mulheres, o que confirma mais uma vez a apropriação da ideia essencialista sobre as identidades masculina e feminina, na medida em que o paradigma "homens não se tocam" também significa implicitamente: "homens não devem ser sensíveis e carinhosos como as mulheres são ('naturalmente')". Nas microcenas 2, 3 e 4 é possível perceber que a questão do romance só é ativada sem a motivação do professor quando se trata de um homem e uma mulher. Na relação homem/homem, além do aspecto amoroso não ter sido mencionado, mesmo a simples orientação de um abraço causou uma agitação. Na imagem da relação mulher/mulher, temos que a possibilidade do namoro foi lançada, mas somente porque um professor a motivou (linha 11), gerando desconcentração e falatório. Mesmo assim, após o momento de caos, o exercício continuou e os participantes embarcaram na ideia (linha 18). Isso é possível de ser interpretado como demonstrando que a homossexualidade pode não ser comum naquele contexto, mas que isso não os impede de refletir e confrontar o tema, na medida em que são estimulados.

Também na quarta aula foi aplicado o Jogo das Profissões. Neste exercício, os participantes recebiam, por forma de sorteio, uma profissão para interpretarem. As profissões eram repetidas nos papeizinhos para que, ao final, dois participantes se encontrassem atuando a mesma profissão. Assim que os papéis foram distribuídos, Isabel pareceu não querer participar da atividade, demonstrando insatisfação com a profissão que lhe foi atribuída. Entregues todas as profissões, a tarefa dos participantes era de 
construir personagens cuja profissão fosse importante na construção da identidade. A primeira ordem foi para andarem pelo espaço fingindo estar indo comer no Mcdonalds. A segunda foi para fingirem estar indo ao parque, a terceira, à praia, e, por fím, ao trabalho. No trabalho, pudemos perceber quem estava fazendo o quê, na medida em que o professor estimulava a criação de gestos repetidos sobre o que eles entendiam da profissão. Novamente, Isabel pareceu resistente ao exercício: enquanto todos faziam gestos, ela ficou encostada na parede de braços cruzados até ser estimulada pela professora.

Microcena 5

\begin{tabular}{|c|c|c|}
\hline 1 & $\mathrm{P} 1$ & Como é que a sua? \\
\hline 2 & Isabel & Ah, a minha é de programa \\
\hline 3 & & $(($ RISOS $))$ \\
\hline $\begin{array}{l}4 \\
5\end{array}$ & $\mathrm{P} 1$ & $\begin{array}{l}\text { Você não precisa falar. Mas ai ai ela faria ela ficaria assim? ((Isabel está de braços } \\
\text { cruzados)) }\end{array}$ \\
\hline 6 & Isabel & É, fica assim. \\
\hline 7 & P1 & Entendi, perfeito. \\
\hline 8 & & ((RISOS)) \\
\hline 9 & $\mathrm{P} 1$ & Tá certo. \\
\hline
\end{tabular}

Os participantes, ao fazerem os gestos, acharam os seus pares e, em dupla, pedimos que eles atuassem as profissões. Isabel se recusou a fazer, deixando Rafaela, sua dupla, atuar sozinha: Rafaela andou pela sala fingindo rodar uma bolsinha. Referente à atuação de outras profissões, na performance das meninas que atuaram o trabalho de um "policial", uma das participantes acabou falando em voz alta "ah, meu Deus, como vou fazer um homem?" e isso foi questionado no final da atividade.

\begin{tabular}{|c|c|l|l|}
\hline 1 & P1 & E como é que foi quando você pegou o policial ... você nem mesmo imaginou que poderia 6 \\
2 & & ser uma mulher sendo policial. \\
\hline 3 & Ana & Não. \\
\hline 4 & P1 & Já pensou logo que era um homem (.) por quê? \\
\hline 5 & Ana & [Foi]. Sei lá, acho que é porque tem muito mais homem do que \\
& & mulher. \\
\hline
\end{tabular}

A atuação de Ana nos mostra o quanto certas profissões vêm fixadas com determinadas identidades de gênero de modo tão naturalizado que nos esquecemos de desvencilhá-las sem que haja estímulo para isso. Com base no que diz Butler, podemos conjecturar que a repetibilidade do fato de encontrarmos muito mais policiais homens do que mulheres dá a aparência natural ao paradigma de que esta é uma profissão destinada ao público masculino. Durante o exercício, houve uma disputa entre a identidade de gênero da atriz e a identidade de gênero fixada à profissão, sendo que a segunda parece ter se sobressaído à primeira, apagando a identidade pessoal de Ana.

Ao final de todas as performances, Isabel, que havia ficado de fora, pediu para interpretar um homem. Permissão concedida, a participante foi ao meio da sala ajeitando o casaco, pôs a mão no órgão genital, abriu o zíper e fingiu urinar. Surpreendeu a todos, 
gerando muitos risos durante a aula. Devido a este ato inesperado, no fim da atividade, os professores decidiram conversar sobre o assunto.

\begin{tabular}{|c|l|l|}
\multicolumn{1}{l|}{ Microcena 7} \\
\hline 1 & P1 & Você quer falar como é que foi? \\
\hline 3 & Isabel & Não. \\
4 & P1 & $\begin{array}{l}\text { Você não fez porque:: era uma coisa meio difícil mesmo de fazer, você não:: mas } \\
\text { quando você fez o homem você fez com muita facilidade e fez uma parada bem }\end{array}$ \\
\hline 5 & Isabel & \multicolumn{1}{c|}{ [Ah, o homem, o homem.] Homem é mais fácil. } \\
\hline 6 & P1 & Homem é mais fácil do que uma fazer uma garota de programa? \\
\hline 7 & Isabel & Claro. \\
\hline 8 & P1 & Você poderia sei lá (.) desfilar e:: porque porque pra Rafaela foi tranquilo né fazer assim \\
\hline 9 & Isabel & \\
\hline 10 & P1 & $\begin{array}{l}\text { Ela teve a criatividade dela, né. E no seu caso eu achei muito interessante porque pra mim } \\
\text { fazer o homem poderia ser até mais difícil do que >sei lá<e fazer uma::, entendeu? Eu não }\end{array}$ \\
11 & & sei se eu teria coragem até de fazer um cara mijando. Eu achei que você teve coragem de \\
13 & & fazer quando você fez o homem. Então, assim, é realmente uma coisa relativa não dá pra \\
14 & & saber o que que vai ser difícil pra um o que que vai ser difícil pro outro. \\
\hline
\end{tabular}

É difícil estabelecer quais foram as dificuldades que impediram Isabel de atuar a profissão "garota(o) de programa". No mínimo, imaginamos que devam existir muitos estigmas, na maior parte das vezes opressores, em relação à profissão. $\mathrm{O}$ fato é que, por alguma razão, ela rejeitou completamente a personagem, e o curioso, foi a forma como interpretou o homem, já não bloqueada, mas completamente espontânea. A sua performance caricaturou a identidade masculina ressaltando o estereótipo do homem desleixado, sujo e mal educado, ou seja, não se interromperam os paradigmas. Mesmo assim, foi um ato corajoso e inesperado da parte de Isabel. Suas motivações, não sabemos, mas sabemos que performar uma identidade estereotipadamente masculina foi mais confortável do que estar na pele de uma mulher prostituta.

A próxima atividade chama-se Jogo do Retrato, um jogo aplicado na quinta aula da oficina. Neste exercício, o participante é convidado a expressar com o corpo - através de uma fotografia, ou seja, uma imagem congelada - um tema escolhido. Os outros participantes devem adivinhar o tema retratado, e, quando isso acontece, todos são convidados a tentar expressar aquele mesmo tema de uma forma diferente, para que, assim, se explorem as novas formas de representação.

O primeiro tema sugerido para a fotografia foi masculinidade e o primeiro participante a jogar fez a fotografia de um homem exibindo seus braços. Os outros jogadores, ao tentarem adivinhar o tema, apostaram em temas como fisiculturismo, vaidade, força, beleza, lutador e macheza. Ao ser declarado o tema pelo professor, todos concordaram que o aluno havia feito uma boa representação, e depois, foram motivados a pensar em novas formas. Surgiram, então, mais três imagens para representar o tema "masculinidade", o que resultou nessas quatro possibilidades: (1) uma pessoa exibindo a força de seus braços; (2) uma pessoa pagando ou recebendo dinheiro; (3) Uma pessoa andando pela rua com a mão no órgão genital, coçando o nariz e escarrando e (4) uma pessoa trabalhando como segurança/guarda. 
O participante criador da fotografia 2 foi questionado sobre porque um homem pagando ou recebendo dinheiro representaria masculinidade, ele afirmou que essa era uma característica típica do homem: trabalhar para colocar o dinheiro dentro de casa. Novamente, todos concordaram que essa era uma boa representação. Todas as outras imagens foram bem aceitas entre o grupo, então, foi a vez de tentarmos outro tema: feminilidade. A primeira participante ajeitou o cabelo e fez uma pose colocando a mão na cintura. Os outros alunos apostaram em temas como beleza, modelo, revista, fofura, delicadeza, paniquete e sensibilidade. Mais uma vez, ao ser declarado o tema, foi de acordo geral que a imagem cumpria o seu dever. Curiosamente, tivemos também mais três representações, chegando-se a quatro possibilidades novamente: (1) uma pessoa posando com a mão na cintura; (2) uma pessoa segurando um bebê e cozinhando no fogão ao mesmo tempo, (3), uma pessoa fazendo as unhas de alguém e (4) uma pessoa se maquiando.

É importante notar que as noções de masculinidade e feminilidade foram igualmente associados por eles a: (1) características estereotipadas de cada identidade de gênero, (2) funções que o homem e a mulher geralmente recebem e exercem na sociedade e (3) profissões grampeadas a uma identidade de gênero específica.

Na primeira representação dos dois temas trabalhados, tanto em "masculinidade" quanto em "feminilidade", os participantes expressaram uma exaltação de características estereotipadas da noção de feminino e de masculino. Por exemplo, na primeira representação de masculinidade, temos a imagem do homem que exibe seus braços, ou seja, uma exaltação de qualidades como força física, brutalidade e firmeza, todas recorrentemente concebidas como masculinas. No caso da feminilidade, obtivemos a representação da mulher que posa exibindo o corpo, o que traz, assim, a exaltação de qualidades como vaidade, beleza, e sensualidade, todas recorrentemente associadas à identidade feminina. A terceira performance de masculinidade e a quarta de feminilidade parecem ser do mesmo tipo também. Tivemos a representação do estereótipo da mulher vaidosa - aquela que passa horas se maquiando e se arrumando para ser bela e sensual e tivemos a representação do estereótipo do homem desleixado, sujo e mal educado. Ambos os casos contribuindo com a reiteração da norma e do estereótipo "o que é ser e agir como homem ou mulher".

$\mathrm{Na}$ segunda representação de cada tema, os participantes produziram algo relacionado à função construída e estabelecida para essas duas categorias (homem/mulher) na sociedade. Por exemplo, no tema masculinidade, obtivemos a imagem do homem que precisa trabalhar para por dinheiro dentro de casa, e, no tema feminilidade, apareceu a imagem da mulher que permanece no lar cuidando da casa e dos filhos.

Por fim, percebemos que ambos os temas receberam uma representação vinculada a uma profissão geralmente executada por um homem ou uma mulher, o que nos remete ao Jogo das Profissões - na situação do emprego "policial", em que percebemos que certos ofícios vêm com identidades de gênero fixadas. No caso dos temas do Jogo do 
Retrato, tivemos, respectivamente, a profissão do segurança/guarda, grampeada à identidade masculina, e a profissão da manicure, grampeada à identidade feminina.

Foi uma atividade bastante proveitosa para analisarmos como as identidades de gênero são representadas dentro daquele contexto. Tivemos representações essencialistas, que não desconstruíram os rótulos esperados. Mas, apesar deste fato, percebemos também que os alunos conseguem desconstruir paradigmas e regimes de verdade sobre gênero na medida em que estes são discutidos e problematizados.

Microcena 8

\begin{tabular}{|c|c|c|}
\hline $\begin{array}{l}1 \\
2\end{array}$ & $\mathrm{P} 1$ & $\begin{array}{l}\text { Agora uma coisa interessante de pensar é o homem que não trabalha pra cuidar da casa, } \\
\text { isso na cabeça de - na opinião de vocês seria também possível? Razoável? }\end{array}$ \\
\hline 3 & Cesar & Sim \\
\hline 4 & Joice & {$[\mathrm{Sim}]$} \\
\hline 5 & Cesar & Tem mulher mulher que banca o cara \\
\hline 6 & P1 & [A mulher que banca o cara] \\
\hline 7 & Joice & Inverte o papel, né. \\
\hline 8 & P1 & É, é uma inversão de papeis, na verdade esse papeis tá muito entre aspas \\
\hline $\begin{array}{c}9 \\
10\end{array}$ & $\mathrm{P} 2$ & $\begin{array}{l}\text { A gente a gente tá pensando de forma meio abstrata, vocês recorrentemente no seu no } \\
\text { cotidiano de vocês, no dia a dia vocês conseguem vocês vêm isso? Vocês vêm essa troca? }\end{array}$ \\
\hline 11 & P1 & No dia a dia, é, é bom pensar nisso, aqui, por exemplo, na comunidade \\
\hline 12 & $\mathrm{P} 2$ & Aqui na comunidade vocês já viram essa essa esses papei invertidos? \\
\hline $\begin{array}{l}13 \\
14\end{array}$ & P1 & $\begin{array}{l}\text { A mulher trabalha? A mulher fica mais em casa? É o homem que bota o dinheiro em casa? } \\
\text { É o homem? É o que? Como é que é? }\end{array}$ \\
\hline 15 & Joice & Ó, eu particularmente não, mas eu acredito que tenha eu acharia isso super normal \\
\hline 16 & P1 & Entendi, perfeito. \\
\hline 17 & P3 & O homem botar o dinheiro em casa ou a mulher? \\
\hline 18 & Joice & A mulher. \\
\hline
\end{tabular}

Aproveitamos a atividade para levantar diversas questões: é possível representar a mulher ou o homem em aspectos gerais ou na maior parte do tempo só fazemos recortes que privilegiam um protótipo de gênero específico? Quanto às funções exercidas na sociedade, será que elas não vêm sendo questionadas e subvertidas? Por que associamos certas características a uma determinada identidade de gênero?

Microcena 9

\begin{tabular}{|l|l|l|l|}
\hline 1 & P1 & É legal a gente pensar isso pra pensar que:: nunca uma imagem ela representa o todo. A \\
2 & & gente pode fazer a coisa da feminilidade com a maquiagem, mas isso não vai representar a \\
3 & & mulher de uma maneira geral. Existem tantos tipos de mulher, tanta opção, que é difícil \\
4 & & você, se eu pedir agora pra alguém falar fazer a representação aqui de mulher (.) é muito \\
5 & & difícil, vocês concordam? Porque o que, o que que é ser mulher pra vocês? Pode ser tanta- \\
6 & & eu sou mulher ela é outra ela é outra ela é outra. Então eu poderia simplesmente como \\
7 & & mulher chegar aqui e tá aqui ((fazendo a fotografia de uma pessoa parada)) não tenho que \\
8 & & fazer mais nada, sabe? tudo o que eu fizer vai ser sempre uma representação de um recorte, \\
9 & & de uma visão de uma visão fechada \\
\hline 10 & Cesar & \\
\hline 11 & P1 & Ou é a maquiagem, mas que não é todas que se maquiam, ou é a profissão mas não é \\
12 & & todas que fazem, todas que gostam, todas que são manicure. É sempre uma coisa, cês \\
13 & & entendem mais ou menos assim o que eu to \\
\hline 14 & P2 & \multicolumn{2}{c}{ [É uma das muitas categorias possíveis] } \\
\hline
\end{tabular}




\begin{tabular}{|l|l|l|}
\hline 15 & P1 & [É uma das muitas] é sempre é sempre uma coisa que não é o total, não abrange o total. É \\
16 & & $\begin{array}{l}\text { muito difícil você pegar e pegar o total daquele sentido, feminilidade, existem } \underline{n} \text { formas de } \\
17\end{array}$ \\
\hline
\end{tabular}

$\mathrm{Na}$ décima primeira aula tivemos algumas atividades de reflexão sobre a homossexualidade, as quais trouxeram pertinentes performances discursivas realizadas pelos alunos. Nesse dia, fizemos a leitura da música "Ser diferente é normal", de Vinicius Castro (gravada em 2013, no álbum Som na sala 2012), e iniciamos uma conversa sobre a legalização do casamento gay nos EUA, que era o assunto dos meios de informação na época. Cada aluno leu uma estrofe da música, e, no final, foram incentivados a escolherem uma estrofe favorita. Estes foram os versos escolhidos:

1) "Todo mundo tem seu jeito singular, de ser feliz, de viver e de enxergar"

2) "Todo mundo tem que ser especial, em oportunidades, em direitos, coisa e tal"

3) "Seja branco, preto, verde, azul ou lilás, e daí? Que diferença faz?"

Durante a leitura da música, todos os alunos concordaram que as pessoas são diferentes umas das outras e cada uma deve ser respeitada pelo seu modo de querer viver. Entretanto, ao iniciarmos a conversa sobre a legalização do casamento gay, a postura solidária frente aos preconceitos e intolerâncias se modificou um pouco. Para nossa surpresa, todos os alunos, sem exceção, se posicionaram contra a legalização. O curioso é que aqueles jovens não sabiam da notícia sobre a legalização da união civil de homossexuais em território americano, que vinha circulando amplamente nas redes sociais, eles haviam sido informados através da oficina. A princípio, isso nos fez imaginar que se tratava de um contexto de desinformação sobre certos eventos ou assuntos.

Microcena 10

\begin{tabular}{|c|c|c|}
\hline $\begin{array}{l}1 \\
2\end{array}$ & P1 & $\begin{array}{l}\text { Você gostou desse verso: todo mundo tem seu jeito singular de ser feliz de viver e de } \\
\text { enxergar }\end{array}$ \\
\hline $\begin{array}{l}3 \\
4\end{array}$ & Mateus & $\begin{array}{l}\text { [E de enxergar] Então, cada um tem um modo de enxergar, o meu modo de } \\
\text { enxergar é diferente dele. }\end{array}$ \\
\hline 5 & P1 & E ai no caso, você acha que isso é errado, mas respeita que \\
\hline 6 & Mateus & [É], eu respeito, entendeu? É o modo deles. \\
\hline 7 & P1 & $\begin{array}{l}\text { Mas você não acha que eles podem se casar se eles têm esse jeito de pensar a vida } \\
\text { deles? }\end{array}$ \\
\hline 8 & Mateus & 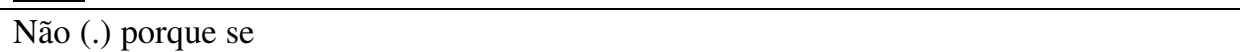 \\
\hline 9 & P1 & [Não?] \\
\hline 10 & Mateus & Assim ... poder não pode porque se não esta lei já existiria há muito muito tempo. \\
\hline 11 & P1 & Mas as leis \\
\hline 12 & $\mathrm{P} 2$ & [Sabia que no Brasil já existe desde 2011?] \\
\hline 13 & Mateus & ${ }^{\circ} \mathrm{Sabia}^{\circ}$ \\
\hline $\begin{array}{l}14 \\
15 \\
16\end{array}$ & P1 & $\begin{array}{l}\text { Não, mas essas, a lei ela é uma coisa que ela ela é construída ao longo do tempo assim } \\
\text { não é uma coisa assim, se a gente for pegar por exemplo, um exemplo, a época de Jesus, } \\
\text { era uma forma de organizacãa soci é social, o a a }\end{array}$ \\
\hline 17 & Cesar & [O tempo foi passando, vai se mudando] \\
\hline
\end{tabular}




\begin{tabular}{|l|l|l|}
\hline 18 & P1 & $\begin{array}{l}\text { No no Egito, na na época do do império Egito, era uma outra forma de organização social } \\
19\end{array}$ \\
20 & & com outras leis, tinha escravidão, entendeu? E isso era lei, entendeu? E ai a escravidão é \\
correta? Até que ponto?
\end{tabular}

Neste primeiro fragmento, é interessante perceber que Mateus utiliza o argumento da lei (linha 10) para deslegitimar a homossexualidade, porém, na mesma medida, os professores desconstroem o paradigma de que as leis trazem verdades fixas, permanentes e imutáveis com o exemplo da escravidão (linha 18). Ao mesmo tempo, os professores demonstram como as leis são socioconstruídas ao longo do tempo (linha 14). A estratégia de dar acesso à lógica da construção social é importante para fazer entender que vivemos sob normas que não representam verdades essenciais e que não são impassíveis a mudanças.

Microcena 11

\begin{tabular}{|c|c|c|}
\hline $\begin{array}{l}1 \\
2 \\
3 \\
4 \\
5 \\
6\end{array}$ & Cesar & $\begin{array}{l}>\text { Eu acho que< eu acho que deveria ter ter muitas melhorias sim, entre aspas, não sei, eu } \\
\text { respeito assim também sabe a pessoa se sentir feliz daquele jeito mas deveria ter uma melhoria } \\
\text { em em outras áreas no Brasil assim por exemplo o que você ai falou que o pessoal que tem } \\
\text { uma condição boa e o uma condição ruim. Acho que poderia fazer outras coisas do que de } \\
\text { estar se preocupando com casamento gay. Pode até ter também só respeitar, eu respeito. }\end{array}$ \\
\hline 7 & P1 & Entendi você acha que - o casamento pra você \\
\hline 8 & $\mathrm{P} 2$ & [Mas é] \\
\hline 9 & Cesar & Não Fo - não focalizar naquilo. Fazer o pessoal vê o casal, pra quê? \\
\hline 10 & $\mathrm{P} 1$ & Você não aceita assim você não aceita a homo a homossexualidade, é isso? Não aceita. \\
\hline 11 & Cesar & Não apoio não. \\
\hline $\begin{array}{l}12 \\
13\end{array}$ & $\mathrm{P} 1$ & $\begin{array}{l}\text { Não apoia. Mas respeita (.) acha que pode ser um direito civil eles quererem se casar? Pode } \\
\text { ser ou não? }\end{array}$ \\
\hline 14 & Cesar & É, pode ser. \\
\hline 15 & $\mathrm{P} 1$ & Pode ser, vamos. \\
\hline $\begin{array}{l}16 \\
17 \\
18 \\
19 \\
20 \\
21 \\
22\end{array}$ & Pedro & $\begin{array}{l}\text { Eu, tipo, como ele falou, primeiro que Deus criou o homem e a mulher. Como é que (.) como } \\
\text { é que como é que duas mulher vão ter vão poder poder ter um filho? Acredito que isso já vem } \\
\text { de antigamente, como você falou, és és antigamente as época antiga e como é que eles vão } \\
\text { poder formar uma família? Assim, tipo, Eu acredito que >eu não tô falando assim tipo<, eu } \\
\text { odeio o os homossexual os os gays. Não, eu eu eu não amo é a prática, é diferente, eu não } \\
\text { amar a prática mas eu amo a pessoa, entendeu? Mas na minha opinião eu acho que errado, } \\
\text { mas ai pessoa tem o livre escolha, livre arbítrio eu acho }\end{array}$ \\
\hline 23 & P1 & Mas aí você acha que eles podem se casar? \\
\hline 24 & Pedro & A pessoa tem o livre arbítrio, né. Eu acho errado. \\
\hline 25 & $\mathrm{P} 1$ & Você acha errado mas o direito de casar você não nega? \\
\hline $\begin{array}{l}26 \\
27 \\
28 \\
29\end{array}$ & Cesar & $\begin{array}{l}\text { Até eles chegar perto de mim, quando eles chegar perto de mim, ô maluco, vira homem ou tu } \\
\text { é mulher, como, perto de mim apoiar essas coisas não. Eu falo que eu respeito assim entre } \\
\text { aspas (.) também porque a pessoa não vai tá do lado do meu lado e eu isso aí cara tá fazendo } \\
\text { certo, não também. }\end{array}$ \\
\hline
\end{tabular}

Podemos perceber alguns argumentos utilizados para posições contra a militância da causa homossexual: a fala de Cesar (linha 1), por exemplo, é sobre outros problemas que o país enfrenta como pobreza e desigualdade social. Na opinião do participante, todas as ações políticas deveriam se atentar para questões sociais específicas - como fome, 
miséria, pobreza - em detrimento total de outras - como as que podem ser associadas à causa LGBT. Isso parece demonstrar que Cesar tenta deslegitimar a causa gay definindoa como menos importante. O participante, desse modo, parece não entender que todas essas causas, seja a homossexual, a negra ou a feminista, formam o conjunto de lutas de minorias.

Já a fala do Pedro (linha 16), parece se pautar em argumentos religiosos e ao que diz respeito à reprodução humana. $\mathrm{O}$ participante parece defender a noção de família tradicional, visto que só concebe a ideia de duas mulheres terem um filho se for pelo critério biológico. Além disso, ao afirmar que "Deus criou o homem e a mulher", ele não só traz à tona a perspectiva criacionista da vida, como parece acreditar que o homem e mulher foram feitos um para o outro de modo essencialista, naturalizando a sexualidade.

Podemos perceber também certa incoerência no discurso de Cesar. Ao mesmo tempo em que ele afirma respeitar os homossexuais e o casamento gay (linhas 1 e 14), demonstra ter uma postura bastante opressora e homofóbica em relação a eles (linha 26).

\begin{tabular}{|c|c|c|}
\hline & & Microcena 12 \\
\hline $\begin{array}{l}1 \\
2 \\
3 \\
4\end{array}$ & P1 & $\begin{array}{l}\text { O que que é um direito civil? (.) a pessoa ter o direito de se casar, a pessoa ter o direito de } \\
\text { dividir os bens, a pessoa ter o direito de ter a certidão lá dela dizendo que ela não é s s } \\
\text { solteira, que ela é é casada. A gente tá falando disso, de direito civil, ela ter direitos de } \\
\text { poder morar com a pessoa, entendeu? }\end{array}$ \\
\hline 5 & Cesar & E o dever dela de fazer filho? \\
\hline 6 & P1 & Mas ela tem esse compromisso o não \\
\hline 7 & Cesar & [como que vai fazer filho com a outra] \\
\hline $\begin{array}{l}8 \\
9 \\
10 \\
11 \\
12\end{array}$ & P1 & $\begin{array}{l}\text { O o casal homossexual em nenhum momento, eu acredito NE dos que eu conheço, em } \\
\text { nenhum momento eles não negam esse desejo de ter uma família. Eles não negam esse } \\
\text { esse esse desejo. Só que assim ou você vai defender uma família tradicional ou você vai } \\
\text { aceitar, ou você vai repensar o próprio conceito de família (.) o que que é família pra vocês? }\end{array}$ \\
\hline 13 & Cesar & [E a mãe? E a mãe da? ] E a mãe da criança? \\
\hline 14 & P1 & Família pra vocês? \\
\hline 15 & Cesar & Família pra mim é mãe que cuida, que dá \\
\hline 16 & Pedro & [Mãe, pai e filho.] \\
\hline 17 & Cesar & É, mãe, pai e filho. \\
\hline $\begin{array}{l}18 \\
19\end{array}$ & P1 & $\begin{array}{l}\text { [Sei lá,] quem? É mãe, pai e filho. Mas quantas crianças } \\
\text { não tem mãe não tem pai? Que vivem com a tia, que vivem com }\end{array}$ \\
\hline 20 & $\mathrm{P} 2$ & [E quando é só a mãe?] \\
\hline 21 & Cesar & Minha mãe? \\
\hline 22 & $\mathrm{P} 2$ & Não, e quando é só a mãe? E quando é só a mãe? Se só tem mãe e filho \\
\hline 23 & Pedro & Vira mãe e pai. \\
\hline 24 & P2 & Vira mãe e pai. \\
\hline 25 & Cesar & ${ }^{\circ} \mathrm{E}^{\circ}$. \\
\hline 26 & $\mathrm{P} 2$ & E quando é só o pai? \\
\hline 27 & Pedro & Vira mãe e pai. \\
\hline 28 & $\mathrm{P} 2$ & Vira mãe e pai e por que que não, e dois pais? \\
\hline
\end{tabular}




\begin{tabular}{|l|l|l|}
\hline 29 & Cesar & Porque na minha opinião a mulher já mulher já nasce com com o dom ali, com a índole de \\
30 & & ser mais feminista, ensinar a criança prum lado. E pai já é - já vai ter as coisas outras coisa \\
31 & & que é mais pra homem, tipo, ensinar a dirigir carro que muitos homens não faz, acho que \\
32 & & tem mais mulher do que homem, não (.) é mais homem do que mulher, jogar futebol (.) \\
33 & & várias coisa. A mulher ensina uma parte, o homem faz outra, não tem como dois homem \\
34 & & ensinar a criança a viver no mundo, no mundo, em geral. \\
\hline 35 & P1 & Gente, vamos lá (.) todos os homens são iguais? \\
\hline
\end{tabular}

$\mathrm{Na}$ microcena 12, podemos notar a presença de falas que expressam opiniões machistas e essencialistas sobre a mulher e sobre o homem. Na linha 5, temos um exemplo disso quando o professor problematiza a questão do casamento gay, que seria um direito civil, e um participante responde: "e o dever dela de fazer filho". Parece que, para ele, a mulher teria o dever e a função de ser mãe, como se esta identidade "materna" fosse irrecusável e inerente à mulher, como se vocações para gerar e criar fossem parte essencial da identidade feminina. Ele se esquece de considerar os vários casos de mulheres que não se identificam com a maternidade e que não desejam construir sua identidade a partir do papel social "mãe". Além disso, o participante também parece não fazer uso dos conhecimentos construídos em atividades como o Jogo do Retrato, que desconstruiu paradigmas sobre funções, empregos e personalidades estereotipadas e naturalizadas para cada identidade de gênero.

Um outro participante, ao ser questionado sobre o que é família, responde através do rótulo da família tradicional (linhas 15 e 16). Desse modo, ele demonstra entender que, para ele, uma família - para ser bem construída - precisaria necessariamente ser composta por uma figura materna (feminina) e uma paterna (masculina). Parece, então, que tanto o homem quanto a mulher nasceriam com qualidades inerentes a eles e que estas os capacitariam a dominar e ensinar habilidades específicas e restritas. Estereótipos como "o homem dirige", enquanto "a mulher costura", "o homem trabalha", enquanto "a mulher cozinha" parecem ser tomados como naturais, e não como socioconstruídos.

Ao final, temos a fala, também essencialista e aos moldes das ideias já mencionadas, de Cesar (linha 29). Nota-se que ele faz um uso totalmente equivocado da palavra "feminista", pois ele a usa num sentido contrário a tudo que a palavra possa significar. Uma possibilidade é que ele tenha querido dizer "feminina". Mesmo assim, ainda seria uma palavra carregada de sentidos subjetivos, que foram discutidos no Jogo do Retrato. Isso nos induz a pensar que, para debater sobre as questões propostas, os participantes apenas acessaram respostas ou argumentos que eles já haviam construído antes da oficina, sem ter incorporado, produtivamente, as discussões travadas ao longo dos jogos.

\section{5) CONSIDERAÇÕES FINAIS}

A aplicação da oficina de Teatro do Oprimido possibilitou avançarmos em reflexões mais teóricas sobre as construções performativas das identidades de gênero dentro do contexto em questão. Em especial, ela tornou possível a grupos em idade escolar 
a reflexão sobre desnaturalização de paradigmas e estereótipos. Para além do fato de a iniciativa ter possivelmente contribuído com a construção coletiva de novos saberes sobre gênero, na medida em que foram "contadas e ouvidas" novas histórias sobre o tema, a oficina foi, principalmente, um espaço de acesso a informações e conteúdos amplamente estudados em contextos acadêmicos e intelectuais, dos quais os participantes certamente não tinham tanta aproximação.

Em momentos de jogos ou atividades, percebemos que os participantes construíram ideias antiessencialistas mais facilmente do que em momentos de debate direto, como o da legalização do casamento gay. Isso nos induz a pensar que, apesar de estarem imbuídos de certezas naturalizadas, os participantes são capazes de desconstruir rótulos e estigmas, mas somente na medida em que são estimulados a isso. Isso também demonstra que a desconstrução de paradigmas não se estabelece de forma rápida ou imediata. Não basta interromper a repetibilidade de um discurso hegemônico para que indivíduos se apropriem de novos saberes ou opiniões, é preciso propor a repetição de novas narrativas, a repetição do debate.

Além disso, a proposta da oficina de teatro também serviu como uma alternativa lúdica e artística à educação sexual de adolescentes em espaços pedagógicos, que muitas vezes auxiliam na perpetuação de regimes de verdade. Serviu como um espaço de união entre teatro e política, um espaço para desoprimir, o que Augusto Boal, criador do Teatro do Oprimido, aspirou com sua metodologia. Como Boal (1991) diria sobre seus jogos: "pode ser que o teatro não seja revolucionário em si mesmo, mas estas formas teatrais são certamente um ensaio da revolução" (1991, pg.152).

\section{REFERÊNCIAS BIBLIOGRÁFICAS}

BAUMAN, Zygmunt. Modernidade Líquida. Tradução: Plínio Dentzien. Rio de janeiro: Jorge Zahar, 2001.

BEAUVIOR, Simone. O Segundo sexo: a experiência vivida, $2^{a}$ ed. Tradução: Sérgio Milliet. São Paulo: Difusão Europeia do livro, 1967.

BOAL, A. Teatro do Oprimido e Outras Poéticas Políticas. Rio de Janeiro: Editora Civilização Brasileira, 1991.

BUTLER, Judith. Problemas de gênero: feminismo e subversão da identidade. Tradução: Renato Aguiar. Rio de Janeiro: Civilização Brasileira, 2003.

BUTLER, Judith. Corpos que pesam: sobre os limites discursivos do "sexo". In G.L. Louro (ed.) O corpoeducado: pedagogias da Sexualidade. Belo Horizonte: Autêntica, 2000 .

EVELYN, Wograine e BIAR, Liana. Teatro do Oprimido e performances de gênero: uma proposta de Intervenção. Pesquisas em Discurso Pedagógico, número 2, 2015. 
FOUCAULT, Michel. História da sexualidade. Volume 1. Rio de Janeiro: Graal, 1988.

HALL, Stuart. A identidade cultural na pós-modernidade, $11^{\mathrm{a}}$ ed. Tradução: Tomaz Tadeu da Silva e Guacira Lopes Louro. Rio de Janeiro: DP\&A, 2006.

MOITA LOPES, L. P da. Identidades Fragmentadas: a construção discursiva de raça, gênero e sexualidade em sala de aula. São Paulo: Marcado das Letras, 2002

SILVA, Tomaz Tadeu da. "A produção social da identidade e da diferença". In: Identidade e diferença. Rio do Janeiro: Editora Vozes, 2000 p. 73-102. 